\title{
Gadget and The Learning Behavior of The Students Memorizing al-Qur'an in MAN 2 Bandung City
}

\author{
Juju Saepudin ${ }^{1}$, Ahmad Noval ${ }^{2}$, Marpuah $^{3}$ \\ \{saep.17.khasep@gmail.com ${ }^{1}$, akhi.noval@gmail.com ${ }^{2}$, nyaimarpuah@gmail.com ${ }^{3}$ \} \\ The Agency of Research and Development of Ministry of Religious Affairs, Jakarta \\ The Ministry Office of Religious Affairs of Pangandaran Regency, West Java ${ }^{2}$ \\ The Agency of Research and Development of Ministry of Religious Affairs, Jakarta ${ }^{3}$
}

\begin{abstract}
This article presents the results of research on the effects of gadget on the learning behavior of students memorizing Al Qur'an. The study was focused on examining policies regarding the use of gadget, its patterns and its impact on the learning behavior. This research was a case study conducted in MAN 2 Bandung City. The data collection techniques used in this study were observation, interviews, and documentation studies. This study found that MAN 2 Bandung City allowed the students to carry their gadget with the teacher's permission. The use of gadget carried out by the students memorizing $\mathrm{Al}$ Qur'an included the high category, and it had a positive impact. It proved the opinions about the intensity of using gadget and its negative effect on one's activities were not always true. This could be seen from the pattern of the use of gadget in MAN 2 Bandung City.
\end{abstract}

Keywords: Gadget, Learning Behavior, Students Memorizing al-Qur'an, MAN 2 Bandung City.

\section{Introduction}

In globalization era, gadget has a very big influence on human life. This can be seen with the increasing number of gadget users in Indonesia. It becomes easier for a person to carry out a social interaction without having to socialize directly, but only by using intermediary media such as gadgets. Since the presence of gadget, the culture and life of many people have changed. Various activities in various aspects of life are very dependent on technology, including education.

Today's gadget users are not only adults, but children are also familiar with gadgets. They already know and understand the sophistication and various applications contained in gadget. The Center of Communication Studies (Puskakom), University of Indonesia, states that every year the internet users in Indonesia increase continuously. In 2014, the number of internet users reached 88.1 million or $34.9 \%$ of the total 252.4 million population. They used the internet through various gadgets. Most (85\%) used mobile phones, while the rest used laptops, cellular phones, and tablets. The average use of gadget was 1-3 hours per day with various reasons of use [1].

Meanwhile, a survey conducted by the Association of Indonesian Internet Service Providers (APJII) revealed that the internet users in Indonesia in 2017 reached 143.26 million people or around $54.68 \%$ of the total population of 262 million people. Most internet users $(44.16 \%)$ used 
smartphone/tablet to access the internet rather than computer/laptop [2].

Gadget is not only a complementary need, but it also creates a lot of dependency for its users, and even the term gadgetmania (gadget addict) appears due to the high gadget consumption. Gadget becomes very important for today's life that requires high mobility. Gadget is not only used as a means of communication and information, but it also encourages the formation of social behavior that is completely different from existing norms [3]. The results of a study conducted by Techin Asia in 2015 showed that the internet users in Indonesia were dominant in finding news and entertainment, while educational content only 5\% [4].

Students must be continuously motivated in order to make them use gadget and internet as a valuable source of information, and to make the most of digital technology help the learning process, increase knowledge, expand their opportunities and empowerment in achieving achievements and a better quality of life. They can not use a laptop or cellphone and other gadgets during learning activities in class resulting in disregard when learning, thereby reducing concentration and having an effect on poor test results [5].

In addition, Budyatna (2005) states that the use of gadget affects the process of transactional communication [6]. Whereas the most ideal communication approach is transactional, where the communication process is seen as a very dynamic and reciprocal process. If ignored, this will be a trigger for individual behavior and will reduce the warmth and intimacy in the process of teaching and learning activities.

In addition to the negative effects mentioned above, gadget can also have a positive impact if the students are able to utilize the internet for the learning process properly. Various researches on the benefits of the internet for learning have been done. John et al. (2016) found that online learning could increase the student interaction and involvement [7]. The research results of Aberg et al (2016) showed that using the digital learning resources could improve the students' writing abilities [8].

The concept of learning by using gadgets can be relied on learning that uses computers, which are theoretically referred to various terms such as Computer Assisted Instruction, Computer Aided Instruction, Computer Assisted Learning, Computer Based Education, Computer Based Instruction, Computer Enriched Instruction, and Computer Managed Instruction. The use of CAI or its other terms can have a positive impact on learning, especially related to learning outcomes achieved by students. There were several studies related to CAI, such as an experimental study comparing the effectiveness of CAI with conventional learning [9], the impact of CAI in the learning of students with special needs [10], and the impact of CAI on student acquisition in learning [11].

This research had a theme "Gadget and Learning Behavior of the Students Memorizing Al Qur'an in State Madrasah Aliyah (MAN) 2 Bandung City". MAN 2 Bandung City was one of the educational institutions under the Ministry of Religion which also helped to realize the national education goals. MAN 2 Bandung City was one of madrasas with several advantages and specialties in terms of tahfiz (memorization) of Al Qur'an.

In modern era, the study of tahfiz al-Qur'an seemed to be very important to develop especially in the management of learning. Some Muslim communities, including most parents of MAN 2 students, really hoped that their children could memorize Al Qur' an as they did in the past. Even some universities, both public and private, had prepared special achievement programs in the field of tahfiz al-Quran as one of the entry points.

To get the quality of memorization of Al Qur'an, many ways could be done. One of them was by utilizing technological devices, including using gadgets. However, a few teachers in schools and the community assumed that gadget only had a negative impact on students. People who memorized Al Qur'an were more likely to need more time to repeat (muroja'ah) Al Qur'an 
they had memorized. Whereas people who used gadget would tend to use other applications in the gadget, so that it would take up a lot of time, distract concentration, and even waste a lot of time they could use to memorize Al Qur'an. There were even those who thought that gadget could inhibit the process of tahfiz al-Qur'an, because they believed that there were many features that were not in line with manners of a memorizer of Al Qur' an (hafiz).

A special program for learning, such as program "mengaji", was also a supporting factor for one's success in being able to read and memorize Al Qur'an. In this case, the government had also stipulated in the 1945 Constitution Article 31 paragraph 3 related to the establishment of the places of religious learning. The article stated that the government must strive and organize a national education system enhancing faith and piety and noble character in order to educate the nation's life regulated by law [12].

Based on the description above, we have an interest in conducting a research regarding to this theme. This study aims to explain: 1) the policy of MAN 2 Bandung on the use of gadgets; 2) the pattern of gadget usage (application used, intensity, duration, form/type of use) by the students memorizing al-Qur'an in MAN 2 Bandung City; and 3) the impact of using gadgets on the behavior of the students memorizing al-Qur'an in MAN 2 Bandung.

\section{Conceptual Framework}

\subsection{Learning Behavior}

Behavior is all activities carried out by humans in general. Behavior or attitude has a very broad meaning. Allport shows that the attitude does not arise instantaneously, but is arranged and shaped through experience as well as giving a direct influence on one's response [13].

According to Ahmadi and Supriyono (2008), every human behavior leads to a certain task. This can be seen in actions such as study or work, but this also occurs in other behaviors that appear to have no purpose [14]. Based on this, behavior can be interpreted as all activities of humans within themselves in the form of reactions, responses, answers, or replies made by individuals.

Learning behavior is an attitude that arises from students in responding to every teaching and learning activities that occur, showing their attitude whether they are enthusiastic and responsible for the learning opportunities given to them. Learning behavior has two qualitative judgments namely good and bad, depending on the individual who experiences them to respond well or even indifferently. Learning behavior also talks about the learning way which is done by the students. So, it can be concluded that learning behavior is a way or action that contains an attitude towards the implementation of learning techniques carried out by individuals or anyone else in a particular learning time and situation [15].

Learning behavior can also be interpreted as an activity that takes place in active interaction with the environment resulting in changes in knowledge, understanding, skills and attitude values [16]. Actually, the concept and understanding of learning behavior varies depending on the perspective of each person because each individual has his own learning behavior.

Globally, learning behavior can be affected by several factors, namely internal (factors from within students), external (factors from outside students), and approach to learning. According to Baharuddin and Wahyuni (2010), internal factors can be classified into two aspects, namely Physiological aspects and Psychological aspects. Physiological aspects refer to a healthy and fit physical condition which can lead to a positive influence on individual learning activities, while 
the psychological aspects include the level of intelligence of students, the student attitudes, the talent of students, the student interest and the student motivation [17].

The external factors that influence learning can be classified into two groups, namely the non -social environment and the social environment including the school, the community and the family environment. Meanwhile the factor of learning approach refers to the types of student learning efforts which include the strategies and methods the students use to carry out the learning activities [18].

\subsection{Tahfiz al-Qur'an}

Tahfiz al-Qur'an consists of two syllables derived from Arabic, namely tahfi $\underline{z}$ and al-Qur'an.

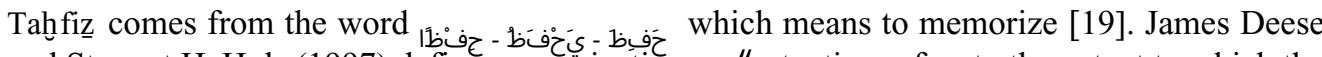
and Stewart H. Huls (1997) define memorization as: "retention refers to the extent to which the material originally learned is still retained, and for getting referred to the portion lost" [20].

The scholars differ on the meaning or definition of al-Qur'an. This is closely related to each function of Al Qur'an itself. According to Caesar E. Farah (2007), al-Qur'an in a literal sense means recitation, reading [21]. Then according to the general term, the understanding of $\mathrm{Al}$ Qur'an is a book that was revealed to Prophet Muhammad, written in the Mushaf, and narrated mutually without doubt [22].

After seeing the definitions of tahfiz $\underline{z}$ and al-Qur'an above it can be concluded that tahfiz alQur'an is a process to keep, protect and preserve the purity of Al Qur'an revealed to Prophet Muhammad by memorization in order to avoid changes and falsification, as well to guard from forgetfulness in whole or in part.

\section{Methodology}

In this study, we used a qualitative approach. The qualitative approach emphasized the process analysis and inductive thinking related to the dynamics of the relationship among observed phenomena and always used scientific logic [23].

This research was conducted in MAN 2 Bandung City, West Java Province. The target of this study was all students of MAN 2 Bandung City who joined the extracurricular program of Tahfiz Club (TC). There were totally 155 students. The data collection was carried out through observation, interviews, documentation studies and questionnaires. Observation was carried out by making a direct visit to MAN 2 Bandung City, especially during tahfiz learning activities. Interviews were conducted with a number of speakers; the Madrasa Staff, the related institutions, and other institutions that had a deal with the learning process in Madrasah Aliyah (MA). The documentation studies were carried out on various sources of information which were relevant to the research topic. The questionnaire was used to find out the pattern of gadget use, such as the intensity of use, the type of application, and so forth.

Furthermore, all collected data were processed and analyzed to produce a description regarding the impact of gadget on the behavior of students memorizing Al Qur' an in MAN 2, Bandung City. The data analysis techniques used in this study followed the flow of qualitative data analysis developed by Miles and Huberman (1994), covering the stages of: 1) data reduction, 2) data presentation, and 3) drawing conclusions and verification [24]. 


\section{Result and Finding}

\subsection{The Model of Tahfiz Al-Qur'an Development in MAN 2 Bandung City}

The development of tilawatil al-Qur'an such as memorizing al-Qur'an $30 \mathrm{juz}$ and reciting it using the art of reading Al Qur'an in accordance with qaidah was not something easy. It required a lot of effort and careful planning, especially in adolescents. However, the students of MAN 2 Bandung City, who were active in the Tahfiz Class, spent their time wrestling Al Qur'an. They felt happy and enjoy with activities of memorizing Al Qur'an, even though the time was interrupted by the main learning activities according to the curriculum of MAN 2 Bandung City, namely from 6:30 to 15:30 WIB.

Based on this, the management of MAN 2 Bandung City believed that a good educational institution must be well managed; a good school was determined by a good management, and a good management began with a good planning. A good planning certainly paid attention to various factors that could support the success of the goals of Madrasa, one of which was to build the generation of Qur'an.

In line with the management of tahfiz al-Qur'an development in MAN 2 Bandung City, the objectives of developing the tahfiz program were: 1) incrasing understanding and knowledge about Islamic; 2) improving Islamic life skills for the younger generation; 3) enhancing and strengthening confidence in the principles of Islam; 4) fostering and creating the generations of al-Qur'an lovers by being a memorizer of Al Qur'an and the readers of Al Qur' an who were able to thrill the heart, so as to strengthen their own faith and the faith of their listeners; and 5) building the character of ulil albab generation.

Tahfiz program was a basic concept of religious education developed in MAN 2 Bandung City. This concept referred to the vision and mission of MAN 2 Bandung City, namely providing excellent services to students in realizing the young generation of ulil albab. The basic principles of tahfiz education development in MAN 2 Bandung City consisted of 1) Education: strengthening the students' mental and spiritual through the inculcation of religious concepts and theories; 2) Learning: strengthening the students' mental and spiritual through strengthening skills in the field of tahfiz and qiro'at so as to form a solid life skill and ready to face the challenges of the world; and 3) Coaching: strengthening the students' character through habituation education especially to the members of the tahfiz and qiro'at development units, which were expected to be a pioneer of all students in MAN 2 Bandung City.

The Tahfiz program in MAN 2 Bandung City referred to the laws and regulations in the education generally, and referred to the program in MAN 2 Bandung City specifically. So, the foundation of the Tahfiz program in MAN 2 Bandung City were: 1) the Law, Number 20 of 2003 concerning the National Education System; 2) the Government Regulation, Number 19 of 2005 concerning National Education Standards; and 3) the Work Program of MAN 2 Bandung City in 2018-2019.

The implementation of the Tahfiz program in MAN 2 Bandung City was packaged in two activities; the Movement of Memorizing Al-Qur'an (called GEMA) and the Tahfiz Club (TC) extracurricular activities. GEMA activities were carried out every morning with tadarus or muraja'ah program with the companions of tahfiz ambassadors chosen through the hafiz graduation based on the curriculum calendar. TC activities were carried out every Wednesday and Friday after school and Saturday morning. TC evaluations were carried out annually by inviting experts and were carried out on an extracurricular calendar. This year there were 155 TC members consisting of the class 10-12 from various majors. 


\subsection{Gadgets and the Learning Behavior of Students Memorizing Al-Qur'an}

\subsubsection{Madrasa Policy Regarding the Use of Gadget}

The impact of the device could be negative, and it could also be positive in education. However, this did not change the strategy of MAN 2 Bandung City to make gadget become a part of facilities and infrastructures in teaching and learning activities. This could be seen in the rules applied in MAN 2 Bandung City. There were 12 rules, one of which was the allowance of the students to bring mobile phones to madrasah, but their use must be approved by the teacher and should not be activated during worship and learning activities that do not require media devices.

Those rules were based on the agreement of the school with parents conducted at the beginning of the school year. The process was long because not all parents agreed, but because nowadays gadget had become a tool to deliver important needs for students' communication with parents, especially when picking up or communicating such as for online transportation messages, the madrasa made a decision on the gadget use as stated in the regulation (Asep Encu, interview, February 28, 2019).

The results of interviews with several teachers in MAN 2 Bandung City showed the students were allowed to bring gadgets to school, but when teaching and learning activities they should not be used, except for certain lessons using smartphones. MAN 2 Bandung City through its teachers had an interest in using the internet for learning. The students were accustomed to using the internet to support learning through assignments and other forms of enrichment. The efforts to habituate the use of the internet or cellphones for learning purposes had a positive impact, so that the gadget and the internet were often used as learning resources by the students of MAN 2 Bandung City (Momon Sudarma [Vice Principal], Sholehudin [TC Coordinator], Imas Suryati [GC Coordinator] on March 1, 2019).

\subsubsection{The Pattern of Gadget Usage}

In the current era of globalization, technology was very influential in life. One of them was electronic media such as gadgets. Various kinds of electronic media including television, computers, laptops, tablets, mobile phones, and so on were created to facilitate daily activities and obtain various information. The following was the electronic media that were often used by the students memorizing Al Qur'an in MAN 2 Bandung City: 


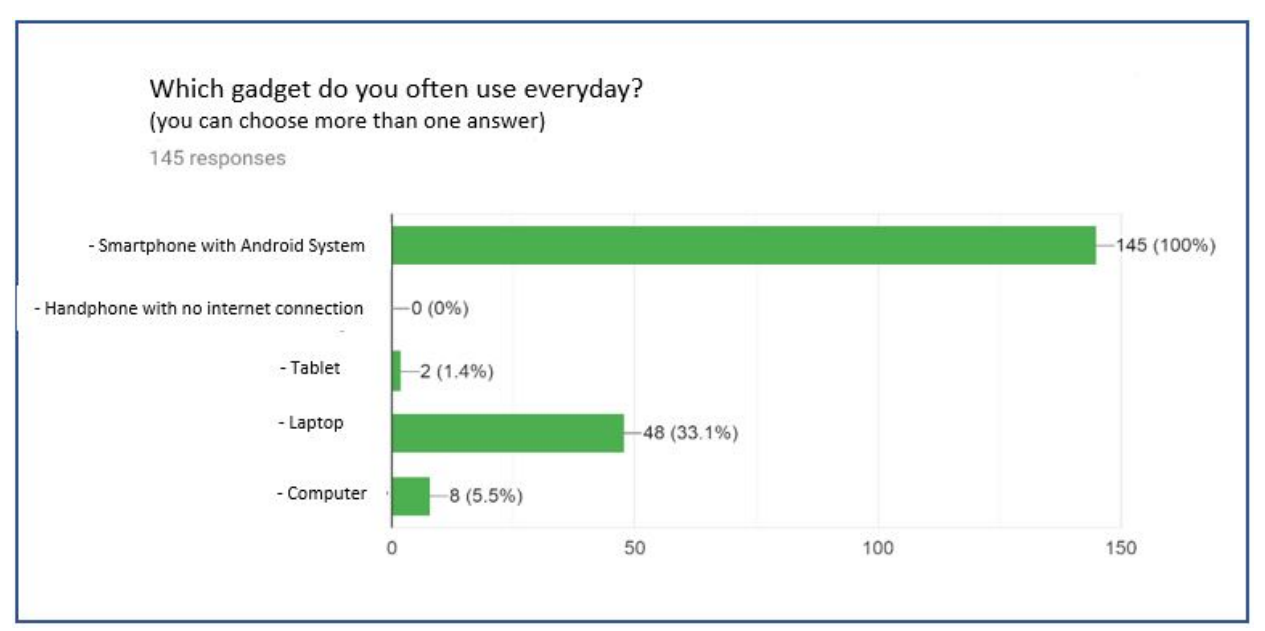

Fig. 1. The graphic of the type of the used gadget.

Based on the results of the questionnaire, it is known that all students who took part in the Tahfiz Club MAN 2 Bandung City often used Android-based smartphones or cellphones. This was due to the increased capacity and technology of smartphones, their use was more practical and flexible, and the price was increasingly affordable by various levels of society, including students. Especially in the city of Bandung many public places provided free internet facilities, so they could anytime and anywhere use the internet. The following was the duration of internet usage among the students memorizing Al Qur'an in one day:

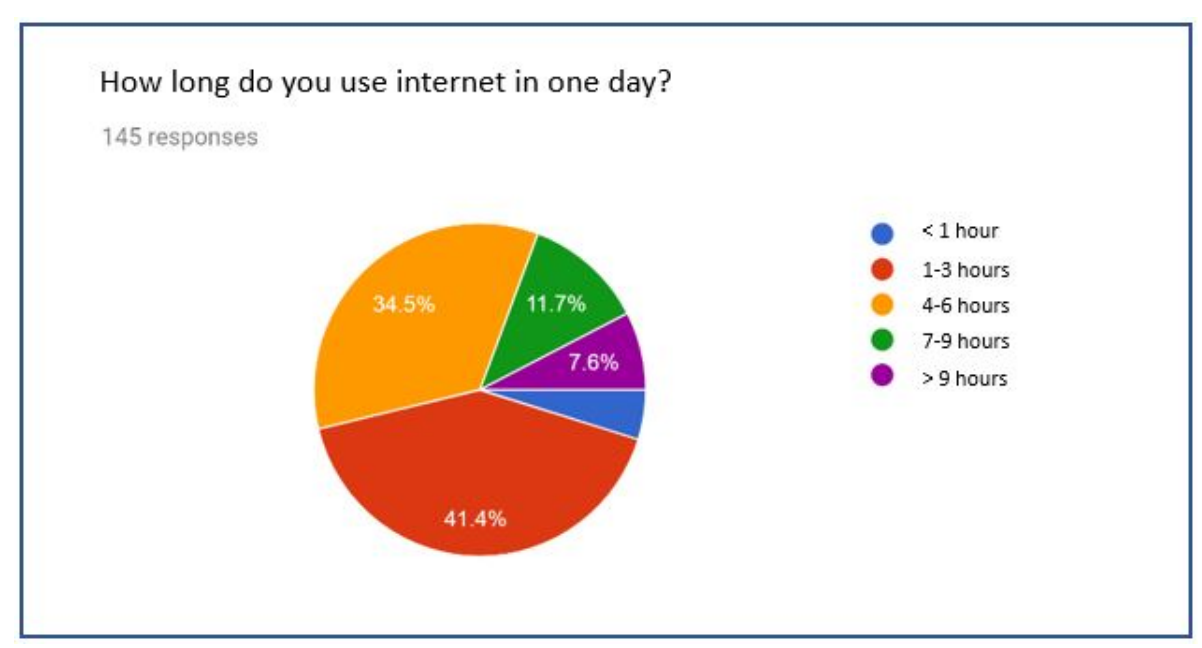

Fig. 2. The graphic of the duration gadget usage in one day.

Based on the diagram above, the majority of students memorizing al-Qur'an at MAN 2 Bandung City used the internet through gadget for 1-3 hours in a day or around (41.4\%), and only few of them used less than one hour. This means that every day students were never 
separated from the use of the internet. They were accustomed to using various gadgets, especially smartphones.

This showed that the daily activities of the students memorizing al-Qur'an could not be separated from various gadget products, especially mobile phones or smartphones. This condition reinforced the opinion of Hidayat (2012), which stated that the media which were very influential in the present time were mobile phones, because mobile phones could be used as a communication tool, information source, study media, and entertainment media [25].

The former and the updated gadget were very different. In the past they were only used as a telephone and SMS communication tool, but with the very advanced technological advances in the present time they were provided with various types and interesting features such as: online games, mp3, digital Al-Quran and so on. The following services were often accessed by the students memorizing Al Qur'an:

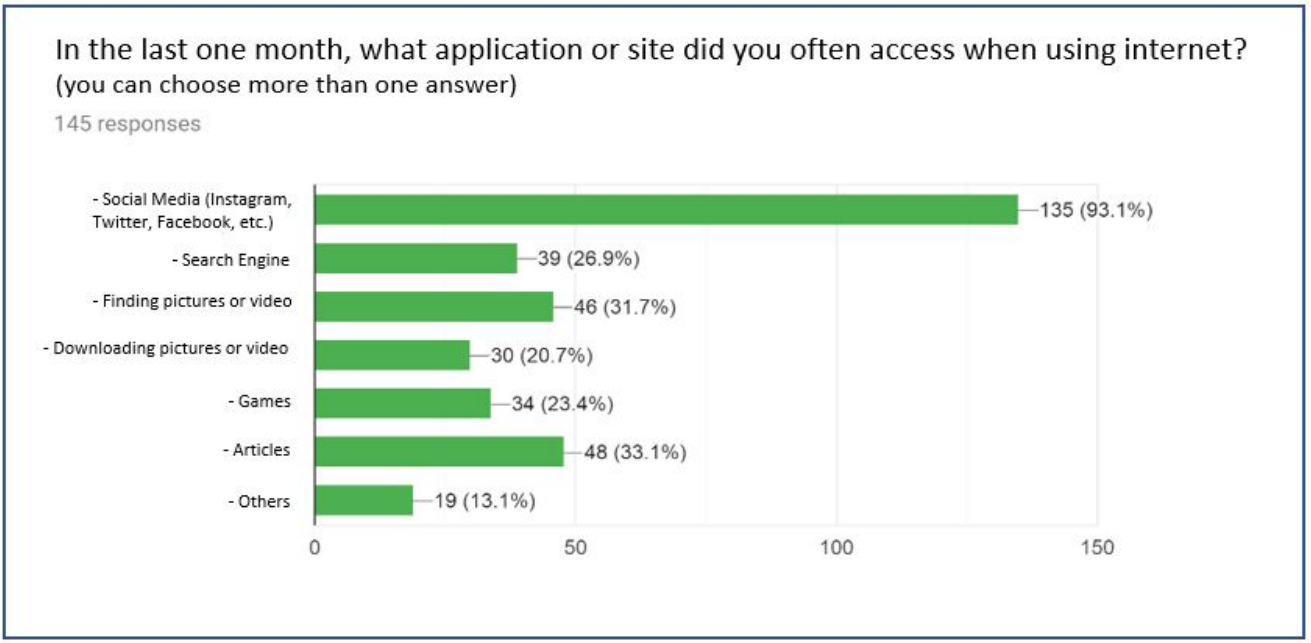

Fig. 3. The graphic of the application usage.

The data above explains that the students memorizing al-Qur'an at MAN 2 Bandung City used the internet from various gadgets for various purposes. Few students chose just one need for internet use, and most students chose answers to more than one choice. The table illustrates that the use of application on the gadget for social media is the highest ranking $(93.1 \%)$, and it was followed by searching for articles $(33.1 \%)$, seeing pictures/videos $(31.7 \%)$, using search engines $(26.9 \%)$, playing games $(23.4 \%)$, downloading pictures/videos $(20.7 \%)$, and other needs $(13.1 \%)$.

The use of social media was the highest ranking in the use of the internet. This was in line with trends in society. The reality was that people were generally very fond of using social media such as Facebook, WhatsApp, Twitter, Instagram, and so on. This fact was supported with the global web index data (Youth manual, 2017), which stated that the number of internet users in the world was more than 3.8 billion people, with as many as 2.9 billion users actively using social media [26]. So the world population was currently in a trend to use social media. In Indonesia, social media users, especially the user of Facebook was ranked in the fourth in the world, after the United States, India and Brazil [27]. 
Mobile phones that previously became a luxury thing and were only owned by people with high economic level can now be owned by the lower classes of society ranging from children to adults. Almost all levels of society used mobile phones, and institutions were no exception. Mobile phones were also available at formal and informal institutions. The following was the purpose of internet access made by the students memorizing al-Qur'an at MAN 2 Bandung City.

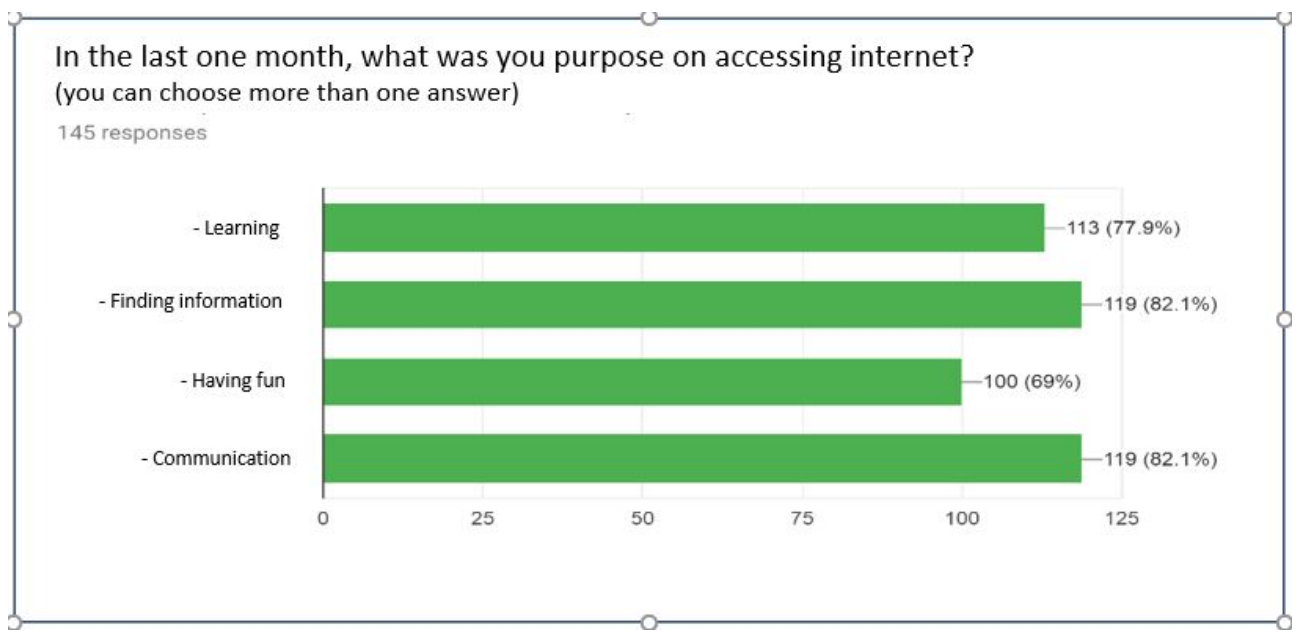

Fig. 4. The graphic of the purpose of accessing internet.

The location of MAN 2 Bandung City was close to UIN Sunan Gunung Djati. This position was advantageous for MAN 2 students to access campus-related information. There were various tourism places in Bandung providing free internet access. MAN 2 Bandung City students included the ones who used internet access in public places, as shown in the following graphic:

Which place do you prefer using smartphone to access internet? (you can choose more than one answer)

145 responses

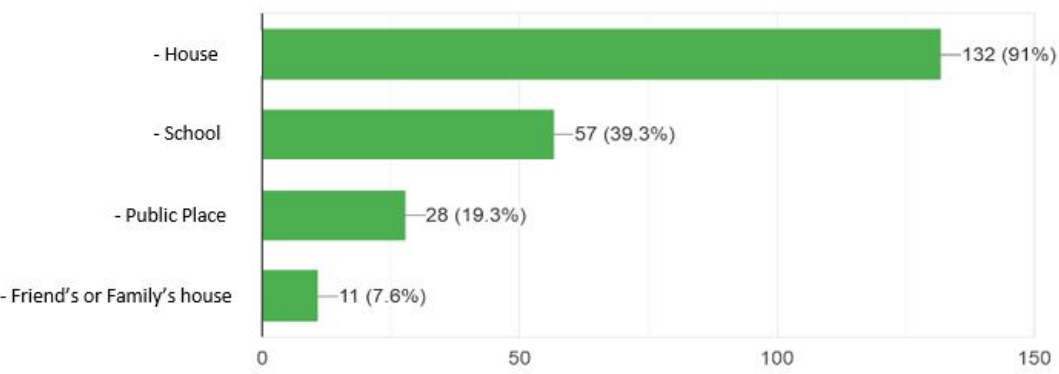


Fig. 5. The graphic of places for accessing internet.

Based on the data above, public facilities were ranked in the third as a place to use smartphones for internet access, while the first rank was at home and the second was at school. Thus, the role of parents in educating children especially related to the digital era was very important. In many previous studies showed that the use of internet with various types of devices was a necessity. Anyone, including parents, could not prohibit their children. Parent should always guide their children to use the internet for positive things, especially learning at home, so that it could improve the academic achievement of their children.

Controlling the internet usage did not have to be strict. Controlling or supervising needed to be done persuasively while respecting the child's privacy. In this case, the results of Faisal's study (2016) described that educating children in the digital era was by applying an authoritarian parenting approach because children did not like being forced but were persuaded. They must also be supervised by parents [28]. In addition, parents must also be able to understand the variety of applications educating the children, to guide them to play it well and to supervise the use of information media so as to keep them stay in the values of Islamic education.

Children were generally smarter than their parents at using the internet through various devices. So, parents were required to be literate and able to operate various devices used by their children. This was important so that parents were able to monitor and control their children's behavior, including their children's financial condition. They could know the financial expenses of their children. The following was an illustration of the average cost of internet quotas for the students memorizing al-Qur'an at MAN 2 Bandung City.

How much do you spend money for internet quota per month?

145 responses

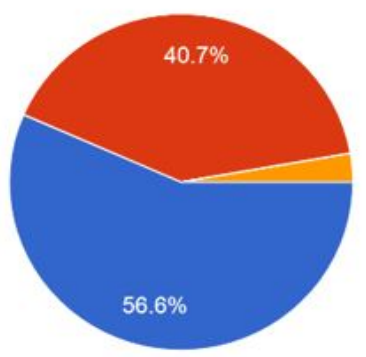

$<50,000$ rupiahs

50,000-100,000 rupiahs

$>100,000$ rupiahs

Fig. 6. The Graphic of the cost of purchasing internet quotas.

\subsubsection{The Impact of the Device on the Behavior of Students Reciting Al-Qur'an}

Based on the results of study conducted by Juwita et al (2015) on high school students in Bandung City, West Java, the use of social media had a positive and negative impact on adolescents, especially affecting adolescent lifestyles [29]. Gadget was used as a means of communication and entertainment among urban teenagers. In addition, the high intensity of the 
use of social media was very influential on the learning behavior of the memorizers of Al Qur'an in MAN 2 Bandung City.

An interesting finding from this study was the high number of students memorizing $\mathrm{Al}$ Qur'an in using gadgets to communicate through social media (93.1\%). Generally, people who memorized Al Qur'an put aside social media, because they had to focus and do a lot of muroja'ah or repetition. People who used mobile media would usually tend to use other features in it, so that it would take up a lot of time and concentration and even reduce the amount of the activities time including adding and maintaining memorization of Al Qur'an.

However, the results of interviews with several students memorizing al-Qur'an in MAN 2 Bandung City showed that they were accustomed to using gadgets and internet, especially to searching for learning materials from the internet, including for the process of memorizing alQur'an. Lailati Dwina Apriani (12-2K) who had memorized 20 juz stated:

"My madrasa teacher said that this handphone was like a knife that would be useful if it was used according to its function and would become mudharat if used for evil. I assume the cellphone does not have a significant negative impact on my memorization, because I use many applications to strengthen my memorization such as WhatsApp. Ioften repeat my memorization to Ustadz Agung (the alumni of MAN 2 Bandung) using WhatsApp and also share my enthusiasm and motivation with my friends. "(Wednesday, March 6, 2019).

A similar opinion was expressed by Fikri Ihsan (XI-IPS) who had memorized 8 juz. He stated that smartphones were very helpful in tahfiz Al-Qur'an because there were many facilities encouraging or motivating him to be more motivated to memorize, such as motivating and inspiring videos, sharing solutions through WhatsApp, and even tahfiz application.

Meanwhile, according to Armijan (11-MIPA) who had memorized 8 juz, cellphone could be disturbing and could also help. The following is his statement:

" $40 \%$ of my cellphone is annoying and $60 \%$ is very helpful because I use it very rarely. Mostly I just see WA and IG chat and the lecturer of Ustadz. In addition to the helpfulness of cell phone, there are also annoying things on it, such as games or the emergence of unexpected negative content that causes me a bit too rare to play it. I use it just for a memorization test and also murottal." (Saturday, March 9, 2019)

The benefits of cellphones were also felt by Agus Fikri Setiawan (12-IIK) who had memorized 14 juz. Previously Agus often watched TV channels, but now he just listened to murottal through smartphones.

Based on the results of some interviews above, this study found that the students memorizing al-Qur'an at MAN 2 Bandung City had a positive opinion on the use of gadgets as a tool of online interaction with their peers. They interacted and communicated with each other easily. Even though the interaction and friendship they made through social media were not directly hand-in-hand, through social media they could be more intimate. This was an evidence that a memorizer of Al Qur' an must stay away from social life.

In fact, there were many ways done by the students memorizing al-Qur'an in MAN 2 Bandung City in order to get the quality of memorization, one of which was by utilizing technological advances, including using smartphone. Smartphones had several features and various attractive designs and could be accessed anywhere and anytime when needed.

\section{Conclusion}


Based on the findings and discussion above, some conclusions can be summarized as follows: First, MAN 2 Bandung City has held a communication with parents with the results in the school order/rules, where the students may bring a gadget if they do not activate it during teaching and learning activities and worship time without permission of the teacher. Second, the gadget use carried out by the students memorizing al-Qur'an in MAN 2 Bandung City is in the high category, especially for the use of social media such as WhatsApp and Instagram.

Third, the use of gadget for the students memorizing al-Qur'an has a positive impact, so it can be said that the opinion about the intensity of using a cell phone with a long frequency and duration is not always true. This can be seen from the pattern of the gadget use carried out by the students memorizing al-Qur'an in MAN 2 Bandung City.

\section{References}

[1] Puskakom UI. 2014. Profil Pengguna Internet Indonesia. Accessed from http://puskakomui.or.id/publikasi/rilis-pers

[2] Asosiasi Penyelenggara Jasa Internet Indonesia. 2002. Infografis Penetrasi dan Perilaku Pengguna Internet Indonesia.

[3] Brotosiswoyo, B. S. 2002. Dampak Sistem Jaringan Global Pada Pendidikan Tinggi. Indosakti, Tangerang

[4] Kusuma N, Hadiyanto. Perilaku Menonton dan Kepuasan Petani terhadap Program Merajut Asa di Televisi TV Trans7. Jurnal Penyuluhan. 2015. 11(1), pp. 60-68.

[5] Glass, Arnold L. and Mengxue Kang: Dividing attention in the classroom reduces exam performance. An International Journal of Experimental Educational Psychology. 2018. pp. 1-15. https://doi.org/10.1080/01443410.2018. 1489046

[6] Budyatna, M. Pengembangan Sistem Informasi: Permasalahan dan Prospeknya. Komunika. 2005. Vol 8, No. 1.

[7] John B, Thavavel V, Jayaraj J, Muthukumar A, Jeevanandam PK. Design of Open Content Social Learning that Increases Learning Efficiency and Engagement Based on Open Pedagogy. TOJET: The Turkish Online Journal of Educational Technology. 2016. 15(1), pp. 20-32.

[8] Aberg ES, Stahle Y, Engdahl I, Nyqvist HK. Designing a Website to Support Students Academic Writing Process. TOJET: The Turkish Online Journal of Educational Technology. 2016. 15(1), pp. 3342.

[9] Ragasa, C. Y. A Comparison of Computer-Assisted Instruction And The Traditional Method of Teaching Basic Statistics. Journal of Statistics Education. 2008. 16 (1), pp. 62-78.

[10] Rice, L. M., Wall, C. A., Fogel, A., \& Shic, F. Computer-Assisted Face Processing Instruction Improves Emotion Recognition, Mentalizing, and Social Skills in Students with ASD. Journal of Autism and Developmental Disorders. 2015. 45(7), pp. 2176-2186.

[11] Qayumi, A. K., Kurihara, Y., Imai, M., Pachev, G., Seo, H., Hoshino, Y., ... \& Lara-Guerra, H. Comparison of Computer-Assisted Instruction (CAI) Versus Traditional Textbook Methods for Training in Abdominal Examination (Japanese Experience). Medical Education. 2004. 38(10), pp. 1080 -1088 .

[12] Kementerian Agama. 2008. Pondok Pesantren dan Madrasah Diniyah Pertumbuhan dan Perkemb angannya. Departemen Agama RI, Jakarta.

[13] Djali. 2013. Psikologi Pendidikan. Bumi Aksara, Jakarta.

[14] Ahmadi, Abu \& Widodo Suoriyono. 2008. Psikologi Belajar. Rineka Cipta, Jakarta.

[15] Soemanto, Wasty. 1990. Psikologi Pendidikan. Rineka Cipta, Jakarta.

[16] Syah, Muhibbin. 2008. Psikologi Pendidikan Dengan Pendekatan Baru. PT. Remaja Rosdakarya, Bandung.

[17] Baharuddin \& Wahyuni, Nur, Esa. 2010. Teori Belajar \& Pembelajaran. Jogjakarta: Ar-Ruzz Media. 
[18] Syah, Muhibbin. 2008. Psikologi Pendidikan Dengan Pendekatan Baru. PT. Remaja Rosdakarya, Bandung.

[19] Yunus, Mahmud. 1990. Kamus Arab-Indonesia. Hidakarya Agung, Jakarta.

[20] Deese, James \& Stewart H. Huls. 1997. The Psychology of Lerning. Mc Graw-Hill, USA.

[21] Farah, Caesar Es. 2007. Islam Belief and Observances. Barron's Education Series, USA.

[22] Anwar, Rosihan. 2004. Ulumul Qur'an. Pustaka Setia, Bandung.

[23] Gunawan, Imam. 2013. Metode Penelitian Kualitatif Teori dan Praktik. Bumi Aksara, Jakarta.

[24] Miles, Matthew B., \& A. Michael Huberman. 1994. Qualitative Data Analysis An Expanded Sourcebook. 2nd Edition. Sage Publications, Inc., California.

[25] Hidayat, Dasrun. 2012. Komunikasi Antar Pribadi dan Medianya. Graha Ilmu, Yogyakarta. [26] Youthmanual. 2017. The Data of Internet Users in 2017. Acccesed from https://www.youthmanual.com/post/fun/did-you-know/data-pengguna-internet-tahun-2017-

[27] Chalim, Saifuddin \& E. Oos M. Anwas. Peran Orangtua dan Guru dalam Membangun Internet sebagai Sumber Pembelajaran. Jurnal Penyuluhan. 2018. Vol. 14 No. 1.

[28] Faisal, Nasrul. Pola Asuh Orang Tua dalam Mendidik Anak di Era Digital. Jurnal An-Nisa. 2016. Vol. IX No. 2, pp. 121-137.

[29] Juwita EP, Budimansyah D, Nurbayani D, Siti. Peran Media Sosial terhadap Gaya Hidup Siswa SMA Negeri 5 Bandung. Jurnal Sosietas. 2015. Vol. 5(1). 